Jakub Pstrąg (0)

Uniwersytet Jagielloński, Kraków

jakub.pstrag@uj.edu.pl

\title{
POZYTYWNA AUTOPREZENTACJA JAKO SPOSÓB UWIARYGODNIENIA WŁASNEJ OSOBY
}

Słowa klucze: autoprezentacja, odgrywanie roli, komunikacja niewerbalna, styl ujawniania emocji Keywords: self-presentation, role-playing, non-verbal communication, style of revealing emotions

\section{Wprowadzenie}

Artykuł przedstawia rolę prezentowanych przez nadawcę pozytywnych emocji $\mathrm{w}$ budowaniu własnego wizerunku publicznego ${ }^{1}$. Emocje pełnią istotną funkcję adaptacyjną, przez co pozwalają na regulowanie wewnętrznych stanów nadawcy, jak również - co jest przedmiotem mojej pracy - odgrywają szczególnie ważną rolę $\mathrm{w}$ procesie interakcji społecznych. Umiejętnie ujawnione i zaprezentowane stany emocjonalne - rzeczywiście odczuwane bądź fałszywie odgrywane - mogą być skutecznym narzędziem perswazji i manipulacji wobec odbiorcy takiego komunikatu (por. Poggi 2005). Nie jest moim zadaniem zbadanie i opisanie psychologicznych aspektów prezentowanych zachowań czy też rzeczywiście odczuwanych przez

1 Do zamieszczonych w pracy materiałów poglądowych (plików wideo) odsyłają tzw. kody QR, do których odczytania służą powszechnie dostępne, darmowe aplikacje na smartfony z systemami iOS i Android, np. QR Code Reader, Czytnik kodów QR, QR Reader for iPhone i wiele innych. Równocześnie podpisy pod odpowiednimi kodami stanowią hiperłącza do tych nagrań. Wyekscerpowany z zapisów telewizyjnych materiał badawczy pochodzi z lat 2007-2019, zamieszczony został w serwisie YouTube i jako taki stanowi integralną część powyższego artykułu. 
nadawców uczuć i/lub towarzyszących tym zachowaniom myśli. Zastosowana metodologia umożliwia natomiast interpretację semantyczną zarejestrowanych reakcji w kontekście komunikacji interpersonalnej.

Błędem byłoby stwierdzenie, że komunikacja ludzka opiera się tylko na naprzemiennej wymianie komunikatów językowych. I chociaż słowo mówione zajmuje prymarne miejsce $\mathrm{w}$ procesie konwersacji, to znaczenia nadawane są także innym kanałom komunikacyjnym. Konieczne jest zatem przyjęcie postawy metodologicznej, która wykorzystuje metody wypracowane nie tylko w językoznawstwie. W centrum mojego zainteresowania będą zatem dwie płaszczyzny: językowa, podlegająca opisowi lingwistycznemu z punktu widzenia gramatyki i semantyki, oraz pozajęzykowa, ale związana z aktem komunikacji. Proponowana przez George’a Lakoffa, Ronalda Langackera czy Zoltána Kövecsesa metoda kognitywna dopuszcza wykorzystanie w analizie osiągnięć nauk innych niż językoznawstwo. Lingwistyka bowiem to nauka zajmująca się ludźmi. Kognitywizm zakłada, że struktury składające się na ludzki system konceptualny są bezpośrednio związane z naszym doświadczeniem.

Szczególne znaczenie w prezentowanej analizie przypisuję elementom komunikacji niewerbalnej. Język, obraz, dźwięk i gest traktuję jako całość nieredukowalną. Systemy semiotyczne w procesie komunikacji wzajemnie się uzupełniają, dopełniają, ale także ograniczają lub przeczą sobie, przez co wpływają na sytuację komunikacyjną i kształtują jej znaczenia. Sens bowiem wyłania się nie z sumy poszczególnych elementów, ale w sposób multiplikatywny (por. Bucher 2015: 80). Słuszniej zatem jest mówić w tym przypadku o potencjale semantycznym zachowań komunikacyjnych, gdyż proces konceptualizacji wymaga przyswojenia i interpretacji komunikatu przez odbiorcę. Mimika i gesty dające się zaobserwować w czasie poszczególnych wypowiedzi nie są aktywnościami, które nic nie znaczą. Stanowią one raczej alternatywną realizację procesów konceptualizacyjnych. Jak pisze Jolanta Antas:

struktura semantyczna wciela się w obrazowość, czyli ta sama sytuacja może być konstruowana na różne sposoby; wszelkimi dostępnymi człowiekowi środkami mentalnego konceptualizowania (Antas 1995: 21).

Gesty nie są więc ozdobnikami, produktami ubocznymi, ale niewerbalnym procesem negocjowania znaczeń. Zatem zarówno warstwa werbalna, jak i niewerbalna komunikatu opierają się na schematach konceptualizacyjnych, które u podstaw z jednej strony mają ludzkie doświadczenie ciała, z drugiej zaś wzorce kulturowe. Potwierdzają to redaktorki serii wydawniczej „Obrazowanie w Komunikacji” (Winiarska, Załazińska 2018), które we wstępie do pierwszego tomu podkreślają fakt, że zarówno zachowania językowe, jak i pozasłowne pozwalają modyfikować wypowiedzi biorących udział w debacie uczestników i na nie wpływać.

Komunikacja taka nie jest przesyłaniem zakodowanych znaczeń, ale ich współtworzeniem, ponieważ sama w sobie jest oparta na zasadzie dialogowości i relewancji (ibid.: 10). 
Szereg badań potwierdza, że obecność gestów odgrywa istotną rolę w trakcie konwersacji zarówno dla nadawcy, jak i dla odbiorcy, a możliwość obserwowania gestykulacji sprzyja lepszemu rozpoznaniu intencji komunikacyjnych (por. Goldin-Meadow 1999: 427).

Do szeroko rozumianej sfery gestów zaliczam zarówno ton głosu, jak i tempo mówienia, a także mimikę oraz gesty rąk. Jak bowiem pisał Maurice Merleau-Ponty: „ciało jest dla nas czymś więcej niż narzędziem lub środkiem: jest naszą ekspresją w świecie, widzialnym kształtem naszych intencji” (Merleau-Ponty 1999: 28). Słowo i gest stanowią zatem alternatywne sposoby mentalnego obrazowania i oba powinny być wykorzystane jako narzędzia służące analizie zachowań autoprezentacyjnych. Jak dowodzą badania (por. Goldin-Meadow 1999: 427), gesty wykorzystywane są zarówno przez odbiorcę (jako źródło informacji), jak i przez nadawcę (jako jeden z elementów wpływających na proces myślenia, wspomagający procesy kognitywne). Zachowania niewerbalne stanowią również potencjalne źródło informacji na temat myśli i stanów mówcy, które nie zostały zwerbalizowane (ibid.: 419). David McNeill (2006) podkreśla zaś, że gesty towarzyszą zazwyczaj informacjom szczególnie ważnym dla nadawcy. Wypowiedź analizować należy zatem, odwołując się do różnych kanałów komunikacyjnych: języka werbalnego, mimiki, postawy ciała, gestów. Żadnego z nich jednak nie należy faworyzować, stanowią one równoprawne środki ekspresji interlokutorów. Głównym celem zarówno gestu, jak i mowy jest w końcu wyrażanie znaczenia tworzonego przez partnerów interakcji, którzy dostosowują swoje zachowania, odpowiadając w ten sposób wzajemnie na swoje działania.

\section{Werbalne i niewerbalne przejawy emocji}

Naturę i funkcję emocji definiować będę w oparciu o teorię Isabelli Poggi (2005). W jej ujęciu emocje to złożony stan wewnętrzny obserwowanego podmiotu/nadawcy prezentowany zarówno w sposób werbalny, jak i niewerbalny. Stan ten obejmować może aspekty poznawcze jednostki, objawy fizjologiczne, zachowania ekspresyjne oraz towarzyszące temu uczucia (pozytywne lub negatywne). Emocje mogą być ujawnione, jako jeden z elementów służących nadawcy do osiągnięcia założonego celu komunikacyjnego (ibid.).

Fakt zainteresowania społeczną oceną jest zjawiskiem powszechnym i dotyczy większości ludzi. Powodem, dla którego sposób odbioru stanowi tak ważny element publicznej interakcji, jest tzw. motywacja egotystyczna (Dymkowski, Pachnowska 1997: 29-33). Mechanizm ten służy ochronie i obronie wartości i tożsamości jednostki, która przeglądając się w lustrze społecznych oczekiwań, zaspokaja głód informacji na własny temat. Tego typu motywacja wynika $z$ silnej potrzeby pozytywnej oceny ze strony innych, z potrzeby aprobaty społecznej, do której ludzie często dążą nawet nieświadomie poprzez zachowania automatyczne lub wystudiowany 
i wyuczony repertuar reakcji. Jeśli zatem motywacja egotystyczna jest zjawiskiem powszechnym i uniwersalnym i towarzyszy nam w codziennych kontaktach z ważnym Innym, to jej działanie szczególnie nasilone będzie w trakcie wystąpień publicznych. Jednym ze sposobów reagowania - i sterowania konwersacją - jest deklarowany optymizm wyrażany między innymi przez prezentowaną publicznie radość.

Radość, obok zaskoczenia/zdziwienia, smutku, strachu, odrazy i gniewu oraz zainteresowania, to jedna z podstawowych emocji ludzkich. Wyniki badań Paula Ekmana (2003: 135) dowiodły, że bez względu na pochodzenie, wykształcenie, miejsce urodzenia i zamieszkiwaną krainę geograficzną tych siedem ludzkich reakcji wyrażanych będzie poprzez makro- i mikroekspresje mimiki twarzy w sposób uniwersalny.

Z koncepcją tą polemizuje Anna Wierzbicka (por. np. 1999). Według badaczki przedstawiciele odległych kultur mogą w podobny sposób kategoryzować określone ekspresje mimiczne, jednak zakres semantyczny jednostek leksykalnych, którymi określaliby dane zachowanie, nie będzie się pokrywał w pełni. Wierzbicka podkreśla, że na przykład ros. mocka (toska) nie jest bezpośrednim tłumaczeniem ang. sadness, a te $\mathrm{z}$ kolei nie posiadają żadnego odpowiednika w języku tahiti z grupy języków polinezyjskich (ibid.: 26). To, co jednak może łączyć użytkowników języka rosyjskiego, angielskiego i tahitańskiego, to podobieństwo myśli towarzyszących przeżywanym procesom wewnętrznym. Refleksja dotyczy przeżywanych odczuć (feelings w terminologii Wierzbickiej), jednak proces ich konceptualizacji, interpretacja językowa to już emocje (emotions), i te nie mogą być porównywane w prosty sposób. A zatem przedstawiciel danej kultury może w pełni przeżywać dany stan emocjonalny, może go także odczytać z twarzy nadawcy, ale nie znać jednego prostego leksemu, którym mógłby go opisać2.

Jak sama autorka jednak przyznaje, Ekman podkreśla, że w kręgu jego zainteresowań nie są słowa określające dane emocje, ale konkretne stany emocjonalne i towarzyszące im ekspresje mimiczne. Potwierdza to słuszność podstawowych dla nauk kognitywnych założeń dotyczących pojęcia stanu poziomu podstawowego. Jak dowodzi między innymi G. Lakoff (2011), pojęcia odnoszące się do emocji są ucieleśnione, a wymieniane przez P. Ekmana emocje podstawowe w uniwersalny sposób korelują z mimiką twarzy. Stanowią one niejako prototypy zachowań, tworzą kategorie emocji, które w określonych sytuacjach przyjmują określone natężenie, na przykład gniew może realizować się jako irytacja, niezadowolenie, oburzenie lub furia, radość jako uciecha, szczęście, rozkosz, euforia itd. Co więcej, Patrick Colm Hogan rozwija tę teorię i dowodzi, że „powszechnie występujący wzorzec narracyjny jest konstruowany w oparciu o międzykulturowe, uniwersalne ramy emocji” (cyt. za: Kövecses 2011: 137).

2 Wierzbicka rozwiązanie tego problemu widzi w rozwijanej przez siebie koncepcji naturalnego metajęzyka semantycznego (Wierzbicka 1999; Kuś 2010). 
Pozytywne emocje, które są tematem tej pracy, ujawniają się głównie nie w warstwie językowej, ale właśnie pozasłownej. Tradycyjnie gesty towarzyszące mowie stanowiły dla badaczy informacje na temat uczuć i emocji mówcy oraz oceny postaw uczestników aktu komunikacji (por. Goldin-Meadow 1999: 420). Gesty poddawane są próbie kontroli, czasem są realizacją świadomego aktu (wizualną, somatyczną realizacją doznawanego stanu), czasem zaś aktem udawanym, jeśli akurat takie zachowanie ma wartość pozytywną w określonej sytuacji. Te ujawnione poprzez kod pozasłowny stany afektywne określają wzajemne relacje i postawy interlokutorów, są też równocześnie źródłem oceny partnera. Mark Leary i Robin Kowalski (za: Wasilewski 2006: 427) uznali przydatność odpowiedniego wizerunku do osiągnięcia pożądanych celów, a subiektywną wartość tych celów oraz subiektywną rozbieżność pomiędzy postrzeganiem wizerunku aktualnego i pożądanego za najważniejsze elementy motywujące do podejmowania działań autoprezentacyjnych. To właśnie owa przydatność, rozumiana jako moc perswazyjna nadawcy, realizuje się w dużej mierze poprzez autoprezentację niewerbalną.

\section{Negocjowanie tożsamości}

Relacje pomiędzy ludźmi i kategoria zdarzeń, do których dochodzi podczas współobecności i dzięki współobecności, stały się dla Ervinga Goffmana podstawowym przedmiotem badań (2006). Według badacza ludzkie zachowania nastawione są za każdym razem na odbiorcę. Niemniej jednak ważnym aspektem kontaktów międzyludzkich - szczególnie rozmowy - jest rola autoreferencyjna, staramy się bowiem nie tylko bawić lub pracować, ale również wysyłać jasne sygnały potwierdzające to, że właśnie się bawimy lub pracujemy, tak jak na dwóch poniższych nagraniach (AVI 1, AVI 2).

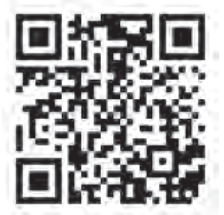

(AVI 1 autoreferencja 01)

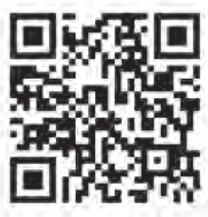

(AVI 2 autoreferencja 02 )

W ujęciu autora Rytuału interakcyjnego akt komunikacji ma charakter spektaklu teatralnego. Biorący udział w interakcji dążą do uzyskania kontroli nad przebiegiem zdarzeń oraz kontrolowania reakcji odbiorców. Impresyjna funkcja działań nadawcy-aktora realizowana jest bezwarunkowo, procesu tego nie da się uniknąć. Partnerzy interakcji czerpią z repertuaru gestów werbalnych i niewerbalnych świadomie, dokonując wyboru i interpretacji swych postaw. Zawarty w tytule pracy Goffmana rytuał pozbawiony jest jednak spontaniczności, charakterystycznej dla występów 
aktorskich, jest raczej tym aspektem życia społecznego, dzięki któremu ustanawiana jest hierarchia, podtrzymywane zaufanie do instytucji i uprawomocniana pozycja jednostki w strukturze społecznej. Oznacza to zatem, że ja musi być nieustannie modelowane przez interakcję. Staje się ono - paradoksalnie - uczestnikiem gry rytualnej, zmuszonym do przestrzegania jej reguł. Tak pojmowana gra, zgodnie z tezami Paula Grice’a, musi być uznana za racjonalną i znaczącą, zgodnie z zasadą kooperacji i podległymi jej maksymami (por. Levinson 2010). Wszystkie więc wypowiedzi i działania biorących udział w dyskusji podlegać będą interpretacji i jednocześnie tworzyć konstrukt ja uczestników. Dramaturgiczny wymiar definiowania sytuacji, według Goffmana, ma czynny udział w kreowaniu porządku publicznego i odnosi się do zasad i schematów nadających sens doświadczeniom i działaniom (por. Hałas 2006: 208). Jest aktywnym procesem zmierzającym do konsekwencji założonych przez aktora, tak by odgrywana przez niego rola była jak najbardziej przekonująca.

Mechanizmem umożliwiającym zręczne manipulowanie kontekstem może być wprowadzający atmosferę radości żart. Tak jak w poniższym przykładzie (AVI 3), w którym cechy prototypowo uznane przez nadawcę za pozytywne stanowić będą centralny punkt odniesienia, przejawy zachowań negatywnych zostały zaś odrzucone jako odrębne od ja (por. Dymkowski, Pachnowska 1997: 29-33).

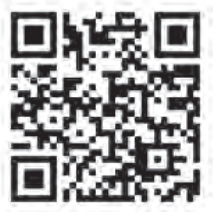

(AVI 3 nie rozumiem słowa byt)

\section{Rodzaje i sposoby autoprezentacji}

Jednym z głównych motywów ludzkiej interakcji jest przedstawienie własnej osoby w pozytywnym świetle, czyli autoprezentacja. Można więc założyć, że czynnikiem branym pod uwagę $\mathrm{w}$ trakcie kontaktu $\mathrm{z}$ innymi jest wywieranie jak najkorzystniejszego wrażenia na odbiorcy, a w konsekwencji możliwość wpływania na podejmowane przez niego decyzje. Naturalnie, projektowany przez nadawcę efekt perlokucyjny wcale nie musi odpowiadać rzeczywistym reakcjom interlokutora. Atrakcyjność, na którą składają się między innymi radość i optymizm, jest warunkiem wiarygodności, a razem wzięte stanowią podstawę skutecznej komunikacji. 
Edward E. Jones i Harold B. Gerard zdefiniowali autoprezentację jako

cechy zachowania uruchamiane przez motywy wzmacniające, które zaprojektowane są, by podkreślić lub ukształtować cechy jednostki, przypisywane jej przez innych [tłum. - J.P., cyt. za: Jones, Pittman 1982: 233]³.

Tak rozumiana autoprezentacja jest według autorów sposobem na podniesienie własnej atrakcyjności, co w konsekwencji skutkować ma większym potencjałem perswazyjnym, jest zatem tylko jednym $\mathrm{z}$ atrybutów ingracjacji. Akty chwalenia się, czyli zachowania służące podkreśleniu własnych wysokich kompetencji i fizycznych, i umysłowych, Gerard i Jones definiowali jako autopromocję. Zaliczyć ją można do szczególnego typu perswazji, której istotą jest nieskrywane wywyższanie się nad odbiorcą, a intencja chwalenia się nie jest zatajona. Autoprezentację rywalizacyjną można zatem potraktować jako przykład symbolicznej agresji, w której funkcja konatywna ukryta jest pod pozorem realizowania funkcji poznawczej. Chwalący kreuje swój obraz, oczekując określonych skutków perlokucyjnych - od zainteresowania po podziw czy zazdrość.

Aby skutecznie porozumieć się z odbiorcą, kompetentny nadawca nie powinien być ani zbyt skryty, ani zbyt szczery w swojej prezentacji. Uważa się (por. Morreale, Spitzberg, Barge 2007: 121), że wyrażanie siebie jest raczej intencjonalnym i dobrowolnym zjawiskiem. $Z$ jednej strony wypowiedź może być zatem sposobem na poinformowanie o cechach interlokutora (otwarciem się, odsłonięciem), z drugiej zaś mieć charakter perswazyjny, czyli być komunikatem mającym za zadanie wytworzenie pożądanego wizerunku (autoprezentacją). Tak rozumiana autoprezentacja nie musi być fałszywa, zawsze jednak służy uzyskaniu konkretnych korzyści. Oczywiście sam akt pozytywnej autoprezentacji nie daje gwarancji powodzenia skuteczności aktów perswazyjnych - i jest tylko jednym z mechanizmów wpływania na odbiorcę komunikatu.

Jones rozwijał koncepcję ujawniania własnego ja, podkreślając jego perswazyjną rolę. Wraz z Thanem S. Pittmanem autoprezentację zdefiniował w końcu jako

zmiany zachowania sterowane dążeniem do zwiększania własnej mocy społecznej, realizowane poprzez ujawnianie - lub odpowiednie kształtowanie procesów atrybucji u obserwatorów - dyspozycji aktora (cyt. za: Szmajke 1999: 20).

W tej koncepcji kluczowe wydają się samoobserwacja i kontrolowanie własnych zachowań. Zachowania strategiczne - zarówno ekspresja werbalna, jak i niewerbalna - odwołujące się do kategorii radości i optymizmu nie są nigdy nieświadome i nie muszą być sprzeczne z wewnętrznym ja nadawcy. Poprzez przemyślane i zaplanowane, a czasem spontaniczne reakcje autoprezenter przedstawia się publiczności

3 „Those features of behavior affected by power augmentation motives designed to elicit or shape other's attributions of the actor's dispositions" (Jones, Pittman 1982: 233). 
jako postać sympatyczna i radosna, a tym samym taka, której można zaufać. Tak jak w dwu poniższych wystąpieniach (AVI 4, AVI 5). Zarówno polski polityk, Tadeusz Cymański, jak i prowadzący talk-show brytyjski celebryta Graham Norton niewerbalnie zachęcają rozmówców do działania. Pełni entuzjazmu i radości zaciskają pięści w geście mobilizacji.

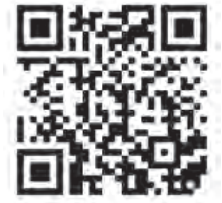

(AVI 4 niewerbalny optymizm o1)

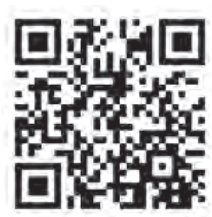

(AVI 5 niewerbalny optymizm 02)

Można zatem wskazać na dwa style ujawniania emocji - styl agresywnej złości, prezentowany wielokrotnie podczas wystąpień telewizyjnych, oraz styl ujawniania uczuć pozytywnych, nieskrępowanej radości i optymizmu, pozwalających na skuteczne funkcjonowanie w życiu publicznym.

Wszystkie zachowania interakcyjne - językowe i niejęzykowe - służące budowaniu własnego wizerunku i mające na celu zjednanie sobie odbiorców zaliczać będę do grupy zachowań autoprezentacyjnych, w których dominować będzie funkcja performatywna, nie zaś informacyjna. W ramach autoprezentacji wyróżnić należy celowe wyrażanie siebie i mimowolne odsłonięcie siebie (por. von Thun 2001: 25). Celem autoprezentacji może być z jednej strony kształtowanie własnej tożsamości poprzez budowanie swojego ja, $\mathrm{z}$ drugiej zaś dążenie do kierowania wrażeniem wywieranym na innych (por. Tice, Faber 2005: 153). Trzecim skutkiem zachowań autoprezentacyjnych, według Marka Leary'ego, jest regulacja emocji (ibid.). Teoria Duvala-Wicklunda (za: Zaborowski 2002: 55) stanowi, że w czasie analizy własnych zachowań, które potwierdzają rozbieżności między rzeczywistymi standardami a aktualnym statusem, jednostka zmienia swoje zachowanie w celu redukcji niepożądanego stanu emocjonalnego. Przystosowawcza zmiana zachowania może przybierać formę od racjonalizacji czynów aż po zmianę standardów. Przystosowanie się do oczekiwań odbiorców możliwe jest dzięki umiejętności sterowania tożsamością, czyli odpowiednim strategiom porozumiewania się, które pozwalają na manipulację własnym obrazem. Tożsamość buduje się wtedy poprzez pożądane w danej chwili akty werbalne i niewerbalne.

\section{Wybrane przykłady wystąpień}

Materiałem, który wybrałem do analizy, są wystąpienia polityków polskich zarejestrowane podczas toczonych w telewizji debat i dyskusji. Przekazywane przez parla- 
mentarzystów treści i sposób organizacji wypowiedzi to często zrytualizowany występ, wpisany w zasady życia społecznego. Pozytywna ocena prywatna i publiczna pozostają dzięki temu w równowadze.

Na przykład w poniższym nagraniu (AVI 6) poseł Cymański przestawia dwie wizje świata: jedną, medialną, przepełnioną negatywnymi ocenami i drugą, w której on i jego środowisko poświęcają się wytężonej pracy na rzecz państwa pomimo braku poparcia ze strony środków masowego przekazu. Wypowiedzi: Mamy $w$ mediach tej krytyki..., prosze mi wierzyć! Zajmujemy się praca, i to niełatwa początkowo towarzyszy gest otwartej dłoni, przesuwającej się poziomo na wysokości czoła. Odpowiadać on może frazie mieć czegoś potąd, czyli 'odczuwać niechęć, rozdrażnienie, przesyt' (WSFJP), i jest niewerbalną realizacją procesu konceptualizacji poczucia przytłoczenia ilością krytyki. Słowom: Zajmujemy się praca, i to niełatwa towarzyszy z kolei gest obu rąk. Otwarte dłonie poruszające się z góry na dół rysują postulowaną przez kognitywizm przestrzeń mentalną, wyraźnie ograniczoną przez zadania, jakie zostały zlecone nadawcy wypowiedzi. Całości towarzyszy pochylenie ciała, skłon podkreślający poświęcenie się, oddanie temu zadaniu. To wszystko jednak nie jest powodem do wyrażania uczuć negatywnych, przeciwnie: mimika twarzy wyraża radość, na twarzy zaobserwować można subtelny uśmiech. Podkreślany przez ekspresje mimiczne optymizm stanowi tło dla treści poddanej obrazowaniu.

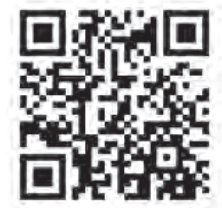

(AVI 6 mamy krytyki pracujemy)

Warto jednak zaznaczyć, że atrakcyjność i kompetencje są parametrami ocenianymi przez odbiorców niezależnie. Psychologowie społeczni podkreślają, że

dążenie do bycia akceptowanym i lubianym przez innych (a także związane z nim myśli jednostki) oraz chęć bycia osobą kompetentną, sprawującą kontrolę i szanowaną są dwiema odrębnymi, ortogonalnymi cechami umysłów społecznych aktorów (Forgas, Williams, Wheeler 2005: 27).

Nie istnieje więc związek pomiędzy subiektywną oceną siebie (w której skład wchodzi zazwyczaj obraz osoby pracowitej, kompetentnej, umiejącej się porozumiewać, uważnie słuchającej i sprawnej retorycznie) a rzeczywistą realizacją aktów komunikacyjnych (por. Tokarz 2006: 314).

W poniższym nagraniu (AVI 7) Jarosław Kaczyński wypowiada słowa: Pan bez przerwy to samo, pan nie wytrzymuje, pan rozumie, że siła moich argumentów jest taka, że pan nie ma żadnych szans, pan nie ma żadnych szans. W warstwie 
werbalnej polityk prezentuje się jako postać silnie przekonana do własnej wizji świata i doskonale kontrolująca sytuację, co dodatkowo podkreślone jest przez powtórzenie ostatniej części zdania. Nie ulega on swojemu adwersarzowi, który - jak wynika $\mathrm{z}$ wypowiedzi - $\mathrm{w}$ wojnie na argumenty musi ulec silniejszemu przeciwnikowi ${ }^{4}$. Ale tym jednoznacznym przekonaniom towarzyszy wyrazista ekspresja mimiczna. Początkowo poważna twarz polityka podczas wypowiadania słów siła moich argumentów zmienia się i zaczyna wyrażać zadowolenie i radość, wzmacniane dodatkowo przez zasiadających w studio zwolenników polityka. Tym samym walczący o wygraną w wyborach parlamentarnych Kaczyński prezentuje się zarówno jako stanowczy mąż stanu, jak i miły i przyjazny strateg polityczny. Według Sik H. Nga i Jamesa J. Bradaca perswazja odnosi się do zmian afektywnych i kognitywnych u odbiorcy komunikatu, a wpływ odnosi się do wszelkich zmian zachowania (za: ibid.: 195). Przyjęcie takiej strategii komunikacyjnej przez polityka, werbalne podkreślanie kompetencji i niewerbalne ujawnianie emocji, przekłada się na pozytywny efekt autoprezentacyjny, a w konsekwencji - na sukces wyborczy.

Partner rozmowy, zasiadający w studio przedstawiciel innej partii, nie jest najważniejszym odbiorcą dla prezesa Prawa i Sprawiedliwości - występujący w telewizji mają bowiem świadomość, że przed ekranami siedzą widzowie, i to do nich właśnie skierowany jest, zależny od kontekstu sytuacyjnego, intencjonalny przekaz. Zgodnie bowiem z założeniami dramaturgizmu Goffmana to publiczność właśnie, jej obecność i potencjalne działania wpływają na dobór odpowiednich technik perswazyjnych. Goście zaproszeni do studia telewizyjnego w trakcie żywiołowej dyskusji nie zapominają zwykle o projektowanym, umiejscowionym w stworzonym przez siebie polu semantycznym odbiorcy. To widz stanowi rzeczywisty punkt odniesienia i to jego właśnie nadawca stara się przekonać do własnej wizji świata. Wiele zaobserwowanych przeze mnie zachowań nie było intencjonalnych, niemniej miały one wartość prezentacyjną.

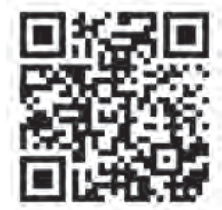

(AVI 7 siła moich argumentów)

Autoprezenter musi być świadomy konieczności poszukiwania kompromisu pomiędzy oczekiwanym odbiorem swojej osoby a wiarygodnością, wybierając te

4 W warstwie werbalnej widać tu przykład użycia klasycznej metafory strukturalnej ARGUMENTOWANIE TO WOJNA. W tym przypadku spór werbalny konceptualizowany jest jako walka wręcz, w której jeden z uczestników jest słabszy i nie wytrzymuje naporu siły argumentów przeciwnika (por. Lakoff, Johnson 1988). 
strategie, które będą najbliższe pożądanemu wizerunkowi i akceptowalne przez odbiorców.

Poziom samooceny ma silny wpływ między innymi na przeżycia emocjonalne. Podstawą do określenia siebie jest tzw. porównanie społeczne - które, według Marii T. Jarymowicz (por. Zaborowski 2002: 237), opiera się nie na szukaniu podobieństw, ale elementów odrębnych, pozwalających zbudować tożsamość. Przykładem właśnie takiej próby wyróżnienia się może być nagranie AVI 8. Zdanie: Pan chciałby, żebym panu powiedział coś ciekawego sugeruje, że sytuacja wyobrażeniowa oparta jest na takich relacjach mentalnych, jak: uważam, myślę. Wydaje się, że można by zinterpretować to zdanie jako: 'myślę, że wiem, czego ode mnie chcesz - oczekujesz sensacji, których ci jednak nie dostarczę’ (postulowany świat premiera nie musi być zgodny ze światem prezentowanym przez dziennikarza). I dalej: naprawdę mam $z$ tym kłopot można eksplikować jako: 'nie potrafię przypomnieć sobie rzeczy, która mogłaby zainteresować, sprostać wymaganiom publiczności'. Być może przedstawione tu zachowanie ma znamiona tzw. działania głębokiego, a zatem celowego ukierunkowania własnych emocji do pożądanego przez siebie stanu, który spowoduje dostosowanie się do sytuacji (por. Turner 2004: 495).

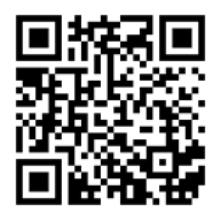

(AVI 8 mogłem się wyspać)

W procesie interakcji ja nadawcy odgrywać będzie zatem znaczącą rolę. Powodować może ono zmianę obserwatora w aktora, co pozwoli mu z kolei skoncentrować się na zadaniu (osobistym, zawodowym, społecznym), nie zaś na własnej postaci. Obserwator i aktor w tym przypadku odnoszą się do tej samej osoby - są to dwie postawy ludzkie, które dokonują różnych ocen i opisu rzeczywistości. Aktor odpowiedzialny jest za zniekształcony obraz siebie i rzeczywistości, dzięki czemu podtrzymana może być pozytywna samoocena. Wydarzenia obiektywne nabierają $\mathrm{w}$ tym ujęciu znaczenia indywidualnego, a informacje o świecie przetwarzane są w sposób subiektywny. Inną rolę odgrywa obserwator, który dokonuje ocen rzeczowych i trafnych, nawet jeśli godzą one w jakiś sposób w samoocenę. Świat obserwatora jest wielowartościowy, a jego postawa - racjonalna, daleka od emocjonalnego zaangażowania aktora. 


\section{Podsumowanie}

Analiza wystąpień publicznych pozwala wskazać co najmniej kilka powtarzających się wzorców zachowań, które można uznać za techniki budowania własnej wartości, czyli jeden ze sposobów uwiarygodniania własnej osoby. Poprzez werbalne i niewerbalne sygnały i wskaźniki interpersonalnego ustosunkowania się (na przykład zachowania grzecznościowe, optymizm, przejawy zachowań konformistycznych) oraz zachowania reaktywne (śmiech, akty tłumaczenia się lub powstrzymywania się od wyrażania emocji) występujący publicznie przedstawia się jako osoba nie tylko kompetentna i odpowiedzialna, a tym samym godna zaufania, ale również swobodna, radosna, sprawiająca miłe wrażenie. Ten zestaw cech może pozytywnie wpłynąć na późniejsze decyzje odbiorców takiego komunikatu, realizując tym samym założony cel perswazyjny.

Występujący przed kamerami dążyć zatem będą do autoafirmacji, czyli uznania siebie za osoby spełnione i wartościowe oraz kompetentne w swojej dziedzinie. Osoby zagrożone utratą twarzy maksymalizują samooceny, wzmacniając poczucie własnej wartości poprzez autoperswazję i racjonalizację własnych zachowań. Tak jak na przykład na poniższym nagraniu, na którym poseł Jacek Kurski dokonuje autokomentarza do własnej wypowiedzi: O! Ta końcówka znakomita! Znakomita!.

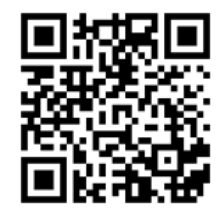

(AVI 9 ta końcówka znakomita)

Interakcja staje się procesem interpretacyjnym i zgodnie z tym założeniem nadawca stara się kontrolować swój obraz w oczach odbiorcy. Dlatego, jak podkreślał Ralph H. Turner (za: Hałas 2006: 59 i n.), przyjęta przez interlokutora rola jest zawsze wytwarzana (role-making), a nie tylko odgrywana (role-playing). Każde pojawienie się w sferze publicznej ma za zadanie potwierdzić pożądany przez występującego obraz własnej osoby. Należy przy tym pamiętać, że wystąpienia publiczne o charakterze perswazyjnym rzadko nastawione są na osiągnięcie natychmiastowych rezultatów, większość z nich bowiem stanowi zaledwie element procesu składającego się na szerszy dyskurs.

Opisane powyżej przykłady dotyczą oczywiście osób charakteryzujących się pragmatyczną koncepcją ja, które wyczulone są na płynące z otoczenia sygnały odnoszące się do własnej osoby. Rzecz ma się zupełnie inaczej w przypadku postaci z pryncypialną koncepcją ja, które większą wagę przywiązują do swoich wewnętrznych odczuć i przekonań. Nie kierują się one opinią społeczną, a akty autoprezenta- 
cyjne wykorzystują nie do wpływania na innych i/lub manipulowania wrażeniem, ale do ujawniania siebie.

\section{Literatura}

Antas J., 1995, Morfologia gestu. Rozważania metodologiczne, [w:] F. Sławiński, H. Mieczkowska (red.), Studia z językoznawstwa stowiańskiego, Kraków, s. 17-24.

BUCHER H.-J., 2015, Rozumienie multimodalne lub recepcja jako interakcja. Teoretyczne i empiryczne podstawy systematycznej analizy multimodalności, [w:] R. Opiłowski, J. Jarosz, P. Staniewski (red.), Lingwistyka mediów. Antologia tłumaczeń, Wrocław, s. 79-110.

Dyмкошsкi M., Pachnowska B., 1997, Ważność samoocen a egotyzm: co wiemy oraz czego powinniśmy się dowiedzieć, „Czasopismo Psychologiczne” 3, nr 1, s. 29-33.

EкMAN P., 2003, Kłamstwo i jego wykrywanie w biznesie, polityce i małżeństwie, wyd. 2 zm., Warszawa.

Forgas J.P., Williams K.D., Wheeler L., 2005, Umyst społeczny - wprowadzenie, [w:] eidem (red.), Umyst spoteczny. Poznawcze i motywacyjne aspekty zachowań interpersonalnych, Gdańsk, s. 21-41.

GofFMAn E., 2006, Rytuat interakcyjny, Warszawa.

Goldin-Meadow S., 1999, The Role of Gesture in Communication and Thinking, „Trends in Cognitive Science" 3, nr 11, s. 419-429, https://doi.org/10.1016/S1364-6613(99)o1397-2.

HAŁAs E., 2006, Interakcjonizm symboliczny, wyd. 2, Warszawa.

Jones E.E., Pittman T.S., 1982, Toward a General Theory of Strategic Self-Presentation, [w:] J. Suls (red.), Psychological Perspectives on the Self, t. 1, Hillsdale, s. 231-262.

KöVecses Z., 2011, Język, umyst, kultura. Praktyczne wprowadzenie, Kraków.

Kuś K., 2010, Teoria emocji Anny Wierzbickiej, „Linguistica Copernicana” 3, nr 1, s. 207-224, https://doi.org/10.12775/LinCop.2010.010.

Lakoff G., 2011, Kobiety, ogień i rzeczy niebezpieczne. Co kategorie mówiq nam o umyśle, Kraków.

Lakoff G., Johnson M., 1988, Metafory w naszym życiu, Warszawa.

Levinson S.C., 2010, Pragmatyka, Warszawa.

McNeill D., 2006, Gesture and Thought, [on-line:] http://moneilllab.uchicago.edu/pdfs/ dmcn_vietri_sul_mare.pdf (dostęp: 19 I 2020).

Merleau-Ponty M., 1999, Proza świata. Eseje o mowie, wyd. 2, Warszawa.

Morreale S.P., Spitzberg B.H., Barge J.K., 2007, Komunikacja między ludźmi. Motywacja, wiedza i umiejętności, red. U. Jakubowska, Warszawa.

POGGI I., 2005, Interacting Bodies and Interacting Minds, [on-line:] http://gesture-lyon2005. ens-lyon.fr/IMG/pdf/Poggi_Lyon.pdf?origin\%3Dpublication_detail (dostęp: 19 I 2020).

Szmajke A., 1999, Autoprezentacja. Maski, pozy, miny, Olsztyn.

Thun F.S. von, 2001, Sztuka rozmawiania. Analiza zaburzeń, Kraków.

TICE D.M., FABER J., 2005, Rola procesów poznawczych i motywacyjnych $w$ autoprezentacji, [w:] J.P. Forgas, K.D. Williams, L. Wheeler (red.), Umyst społeczny. Poznawcze i motywacyjne aspekty zachowań interpersonalnych, Gdańsk, s. 152-168.

Tokarz M., 2006, Argumentacja. Perswazja. Manipulacja, Gdańsk.

Turner J.H., 2004, Struktura teorii socjologicznej, red. A. Manterys, G. Woroniecka, Warszawa. 
WASILEWSKi J., 2006, Retoryka dominacji, Warszawa.

Wierzbicka A., 1999, Emotions across Languages and Cultures. Diversity and Universals, Paris, https://doi.org/10.1017/CBO9780511521256.

Winiarska J., ZaŁaZiŃsKa A., 2018, Multimodalność komunikacji w perspektywie kognitywizmu, [w:] eaedem (red.), Multimodalność komunikacji, „Obrazowanie w Komunikacji”, t. 1, Kraków, s. 7-18.

WSFJP: P. Müldner-Nieckowski (red.), Wielki słownik frazeologiczny języka polskiego. Wyrażenia, zwroty, frazy, Warszawa 2004.

Zaborowski Z., 2002, Człowiek, jego świat i życie. Próba integracji, Warszawa.

\section{Positive Self-presentation as a Way to Authenticate Oneself Abstract}

The article presents an analysis of public speaking in terms of the style of revealing emotions, from self-promotion to self-presentation. Performers show their (desirable) features, building their image and identity, but at the same time they influence decisions of the recipients. Self-presentation behaviours include all activities, both verbal and non-verbal, which, in addition to the persuasion potential, build a positive self-image of the sender and increase his/her attractiveness in the eyes of the interlocutor. The author of the article discusses some examples of such behaviours based on statements and gestures of public figures recorded during television programs, which are perceived as signals and indicators of interpersonal attitude and reactive behaviour. 